\title{
Verbal Abuse in Adolescents During the Covid-19 Pandemic
}

\author{
Rany Ekawati ${ }^{1, *}$ Anisa Nur Rahma ${ }^{2}$ Kartika Alifia ${ }^{3}$ Nadia Regita Ayu Cahyani ${ }^{4}$ \\ ${ }^{1-4}$ Department of Public Health, Faculty of Sport Science, State University of Malang, Malang, Indonesia \\ *Corresponding author Email: rany.ekawati.fik@um.ac.id
}

\begin{abstract}
The Covid-19 pandemic has now spread to all parts of the world, including Indonesia. The existence of this pandemic trigger problems such as mental health disorders in the form of stress and so on that can trigger verbal violence. Verbal abuse or by other names verbal abuse is an act that is verbally carried out continuously which can affect the victim's emotions. The method used in this research is descriptive analytical method. The research sample was 192 people from various provinces in Indonesia aged 10-24 years. The results of this study are uncomfortable feelings due to someone's words which generally occur 1 to 2 times (34.9\%), 3 to 5 times (25\%), 6 to 10 times $(7.8 \%)$, and more than 10 times. times $(21.9 \%)$ and often occurred during high school (30.2\%) and happening now $(24.5 \%)$. The words that parents are uncomfortable with each other or other people at home mostly occur 1 to 2 times (28.1\%), 3 to 5 times (11.5\%), 6 to 10 times $(4.7 \%)$, more than 10 times $(12 \%)$ and occurs in the present $(20.8 \%)$. Uncomfortable words from parents that are done to teenagers are happening now (25.5\%) and are often done 1 to 2 times (29.2\%). The worst impact of verbal abuse is when adolescent try to commit suicide because they feel they are no longer worthy.
\end{abstract}

Keywords: verbal abuse, adolescents, Covid-19 pandemic

\section{INTRODUCTION}

The Covid-19 pandemic has now spread to all parts of the world, including Indonesia [1]. The existence of this pandemic has triggered problems that are not only felt in the medical realm. With the high rate of spread of Covid-19, it requires people to practice social distancing by carrying out all activities at home to minimize contact with other people. Various impacts caused by social distancing policies are fatigue and stress felt by the community. This can trigger the emergence of violence in society [2].

According to the World Health Organization (WHO), violence is defined as the use of physical force and power to threaten others so that it can result in psychological problems, trauma, death, and can inhibit the development process in a person [3]. One kind of violence that can occur in adolescents is verbal abuse. Verbal abuse violance or by other names verbal abuse is an act that is verbally carried out continuously which can affect the victim's emotions. The kind of verbal abuse is saying harsh words to someone, such as insulting, threatening, slandering, intimidating, and demeaning. The impact of verbal abuse is the presence of emotional disturbances, adversely affecting their development, and becomes more aggressive in action [4].

\section{METHOD}

The method used in this study is a descriptive analytical method with a survey method, with distributing questionnaires to the target, specifically adolescents aged 10-24 years who are held out online with a research time span during July-August 2021. This study uses the "Childhood Experiences of Violance" questionnaire. Questionnaire (CEVQ)" from a study by Walsh., et.al (2008).

\section{RESULTS}

\subsection{Respondent Characteristics}

The number of respondents is 192 people who are generally female (69.3\%). In addition, the age of the respondents ranged from 19-24 years (92.7\%) who were in their late teens. For the distribution of provinces to respondents, three provinces were found, namely East Java $(64.1 \%)$, West Java $(10.4 \%)$, and Central Java (10.4\%) (Table 1). 
Table 1. Respondent Characteristics

\begin{tabular}{|c|c|c|}
\hline Characteristics & $\mathrm{n}$ & $\%$ \\
\hline $\begin{array}{l}\text { Sex } \\
\quad \text { Male } \\
\text { female }\end{array}$ & $\begin{array}{l}59 \\
133\end{array}$ & $\begin{array}{l}30.7 \\
69.3\end{array}$ \\
\hline $\begin{array}{l}\text { Age } \\
\text { Early Adolescence (12-15 } \\
\text { years) } \\
\text { Middle Ages (16-18 years) } \\
\text { Late Adolescence (19-24 } \\
\text { years) } \\
\end{array}$ & $\begin{array}{l}2 \\
12 \\
178\end{array}$ & $\begin{array}{l}1.04 \\
6.25 \\
92.7\end{array}$ \\
\hline $\begin{array}{l}\text { Province } \\
\text { Bali } \\
\text { Banten } \\
\text { DIY } \\
\text { DKI Jakarta } \\
\text { Jambi } \\
\text { West Java } \\
\text { Central Java } \\
\text { East Java } \\
\text { Borneo } \\
\text { Lampung } \\
\text { Riau } \\
\text { South Sulawesi } \\
\text { North Sumatra } \\
\text { South Sumatra }\end{array}$ & $\begin{array}{c}1 \\
5 \\
4 \\
10 \\
1 \\
20 \\
20 \\
123 \\
3 \\
1 \\
1 \\
1 \\
1 \\
1\end{array}$ & $\begin{array}{c}.5 \\
2.6 \\
2.1 \\
5.2 \\
.5 \\
10.4 \\
10.4 \\
64.1 \\
1.6 \\
.5 \\
.5 \\
.5 \\
.5 \\
.5\end{array}$ \\
\hline
\end{tabular}

\subsection{Verbal Abuse}

Table 2. Verbal Abuse

\begin{tabular}{|l|c|c|}
\hline \multicolumn{1}{|c|}{ Verbal Abuse } & $\mathrm{N}$ & $\%$ \\
\hline Uncomfortable Feelings due to & & \\
Someone's Words & & \\
1 to 2 times & 67 & 34.9 \\
3 to 5 times & 18 & 25 \\
6 to 10 times & 42 & 7.8 \\
$\quad$ More than 10 times & 21.9 \\
\hline Occurrence Time & 25 & 13 \\
Elementary school & 23 & 12 \\
Middle school & 58 & 30.2 \\
High school & 22 & 11.5 \\
Finished high school & 47 & 24.5 \\
Happening Now & 52 & \\
\hline Verbal abuse & 103 & 27.1 \\
Siblings & 6 & 53.6 \\
School/college/work friends & 2 & 3.1 \\
Neighbor & 11 & 5.7 \\
Boyfriend & \\
Other &
\end{tabular}

One kind of verbal abuse is an act of hurting feelings that causes a person to feel uncomfortable through words. In adolescents, this usually occurs 1 to 2 times (34.9\%). This happens a lot during high school (30.2\%). According to monitoring from KPAI in 2012, violence is often found and carried out in the school environment [5]. Therefore, the perpetrators of this verbal abuse are school/college/work friends (53.6\%) (Table 2).
At the time during the pandemic, forms of verbal abuse in the form of hurting someone's feelings are also still often found. The rate of verbal abuse during the pandemic is also relatively high (24.5\%).

Table 3. Parental Verbal Abuse

\begin{tabular}{|l|c|c|}
\hline \multicolumn{1}{|c|}{ Parental Verbal Abuse } & N & $\%$ \\
\hline Parental Uncomfortable Sayings & & \\
Between Each Other or Others in & & \\
the House & 54 & 28.1 \\
1 to 2 times & 22 & 11.5 \\
3 to 5 times & 9 & 4.7 \\
6 to 10 times & 23 & 12 \\
$\quad$ More than 10 times & & \\
\hline Occurrence Time & 16 & 8.3 \\
Elementary school & 10 & 5.2 \\
Middle school & 24 & 12.5 \\
High school & 19 & 9.9 \\
Finished high school & 40 & 20.8 \\
Happening Now & & \\
\hline
\end{tabular}

Verbal abuse such as uncomfortable words from parents to each other or other people at home also often occurs during the Covid-19 pandemic. Most happened 1 to 2 times $(28.1 \%)$ and happened now (20.8\%) (Table 3). Words that are often uttered by fellow parents also often have a painful effect on the interlocutor. Things like this can trigger conflict in the family.

Table 4. Parental Verbal Abuse

\begin{tabular}{|l|l|l|}
\hline \multicolumn{1}{|c|}{ Parental Verbal Abuse } & $\mathrm{n}$ & $\%$ \\
\hline $\begin{array}{l}\text { Offensive Words that Parents gave } \\
\text { to their Child }\end{array}$ & & \\
1 to 2 times & 56 & 29.2 \\
3 to 5 times & 28 & 14.6 \\
6 to 10 times & 7 & 3.6 \\
More than 10 times & 22 & 11.5 \\
\hline Occurrence Time & 12 & 6.3 \\
Elementary school & 9 & 4.7 \\
Middle school & 24 & 12.5 \\
High school & 19 & 9.9 \\
Finished high school & 49 & 25.5 \\
Happening Now & \\
\hline
\end{tabular}

Often without realizing it, parents often commit violence against adolescents. The violence can be in the form of physical or verbal abuse. Verbal abuse is usually carried out through words that can hurt feelings such as lowering their abilities, considering someone as a source of bad luck, and giving negative nicknames to adolescents [8]. This happens a lot now $(25.5 \%)$ and is often done 1 to 2 times (29.2\%) (Table 4).

\section{DISCUSSION}

\subsection{Analysis of Verbal Abuse in Adolescents}

During the Covid-19 pandemic, verbal abuse is increasingly prevalent. The pressure from various policies has resulted in the number of incidents of verbal 
abuse also worthy of attention. Verbal abuse is an act that is carried out orally which has an effect in the form of violence, both through written and implied words and has an effect on the victim, both physically and mentally [10]. There are several forms of verbal abuse, such as not giving affection to their children, intimidating (threatening, bullying, and shouting), humiliating others, criticizing others, and giving extreme punishments to others [11].

Since Covid-19 suffered Indonesia, the form of verbal abuse, like throwing bad words at others, is classified as verbal abuse that very often occurs in people's lives. There are several things that cause verbal abuse to occur, one of which is related to bad behavior from adolescents. Adolescents are still classified as an unstable age where they try to find their identity and it is very easy to receive information from the outside so that it can lead to deviant behavior. This behavior can cause parents to tend to do various forms of verbal abuse [4].

Screams, hurtful words, shouts, threats or anger can be considered as verbal abuse. A child who gets verbal abuse too often can interfere with the child's social and emotional development. According to the data that has been collected, verbal abuse occurs at various levels in schools ranging from Elementary School (SD) to Senior High School (SMA). This shows that the age vulnerable to violence is at school age. School age is a place where children meet many new friends which can lead to verbal abuse, such as bullying. Verbal abuse also cannot be underestimated because it can have various psychological impacts on the child. Therefore, abuse also deserves attention.

\subsection{Impact of Verbal Abuse on Adolescents}

Stimulation from the environment around children greatly affects the process of growth and development of children to adults. Including one of them is the process of forming a child's character, especially a teenager is also influenced by the surrounding environment. Children tend to more easily catch and imitate the things they notice from the surrounding environment. In this case of verbal abuse, it is very likely that children will do the same thing to others when they grow up [4].

A teenager who experiencing verbal abuse has a tendency to imitate the behavior of his parents. Children will transfer their aggressive feelings to their peers as a form of self-concept. This will have an impact on the social life of children. Children prefer to be alone, have few friends, and like to annoy others [12]. When a child grows up hearing detractor sentences, he will become a critic someday. Parents who are used to criticizing their children or saying uncomfortable things to their children are likely to make children behave badly following the attitudes of their parents. When children experience continuous verbal abuse, children will feel that they are not loved, worthless, unhappy, and do not like all the activities they do. The worst impact of verbal abuse is when children try to commit suicide because they feel they are no longer worthy [13].

Verbal abuse is often found, especially at school age. School is a time when it is still unstable which is indicated by various attitudes, such as being selfish, rebelling and fighting against the rules, and a high desire for things [14]. This causes the child to tend to be unruly and make others able to verbally abuse the child. In the Law of the Republic of Indonesia number 35 of 2014 which is stated in article 1 paragraph $15 \mathrm{a}$, it is stated that violence is anything that can cause children to experience suffering, neglect, and even threats [15]. So, violence is against the law because a child also has the right to grow and develop. Treatment from other people which is included in school-age verbal abuse, including getting bad quotes from parents, bullying friends, threatening children, punishing students, and giving punishments that are too extreme.

The impact can have an impact on the victim's psychological and physical. Usually verbal abuse does not have a physical impact, but will have an impact on the victim's psychology which can damage the victim for several years to come because it leaves a sense of trauma. In fact, according to Soetjaningsih, verbal abuse perpetrated by parents against their children can cause very deep wounds and feelings of children beyond the act of violating. Psychological short-term that can be experienced by victims of verbal abuse are impaired child development, emotional disturbances, lack of social relationships with others, and may have a sociopath or antisocial personality disorder [16]. In addition, the longterm impact that can be experienced by children is imitating what they experience, can have an impact on family violence, and can cause children to do bad things such as suicide [17].

\section{CONCLUSION}

At the end of this study, it can be concluded feelings of discomfort due to a person's words generally occur 1 to 2 times and often occur during high school. Parents uncomfortable words between each other or others at home mostly occur 1 to 2 times and occur now. Uncomfortable words from parents made to adolescents occur a lot now and are often done 1 to 2 times. The impact caused by verbal abuse in adolescents include having a tendency to imitate the behavior of their parents, children prefer to be alone, have few friends, like to disturb others, and later potentially become a detractor. The worst impact of verbal abuse is when a child tries to commit suicide because he feels worthless. 


\section{AUTHORS' CONTRIBUTIONS}

RE: concept and design study, methodology, writing the manuscript; ANR, KA, NRA: data collection, data analysis, writing

\section{ACKNOWLEDGMENTS}

The authors thank to all respondents that participated in this study. We also thank to Faculty of Sport Science, Universitas Negeri Malang that support this study.

\section{REFERENCES}

[1] W. A. Fazraningtyas, D. Rahmayani, and I. R. Fitriani, "Kejadian Kekerasan pada Perempuan Selama Masa Pandemi COVID-19," Din. Kesehat. J. Kebidanan Dan Keperawatan, vol. 11, no. 1, pp. 362-371, 2020.

[2] P. Agung, N. Indra, and P. Satya, "Covid- 19 Dan Potensi Konflik Sosial," J. Ilm. Hub. Int., vol. 0, no. 0, pp. 39-45, 2020.

[3] M. Daher, "World report on violence and health," J. Med. Liban., vol. 51, no. 2, pp. 59-63, 2003.

[4] B. Mahmud, "Kekerasan verbal pada anak," $J$. An Nisa', vol. 12, no. 2, pp. 689-694, 2019.

[5] Y. Yoela, D. H. Tobing, and D. H. Tobing, "Memaafkan Pada Perempuan Dewasa Muda Yang Pernah Mengalami Kekerasan Oleh Orangtua Pada Masa Anak-Anak," J. Psikol. Udayana, vol. 4, no. 02, p. 413, 2018.

[6] L. Maghfiroh, F. Wijayanti, and U. N. Waluyo, "Parenting stress dengen kekerasan verbal pada anak usia sekolah di masa pandemi Covid-19," vol. 12, no. 2, pp. 187-193, 2021.

[7] A. Dariyo, "Memahami Psikologi Perceraian dalam Kehidupan Keluarga," J. Psikol., vol. 2, no. 2, pp. 94-100, 2004.

[8] Y. Fitriana, K. Pratiwi, and A. V. Sutanto, "Faktor-Faktor Yang Berhubungan Dengan Perilaku Orang Tua Dalam Melakukan Kekerasan Verbal Terhadap Anak Usia PraSekolah," J. Psikol. Undip, vol. 14, no. 1, pp.81-
93, 2015.

[9] M. M. Latifah, R. Yulia, Y. D. Arinda, and H. Pratomo, "Kekerasan Dalam Keluarga Pada Remaja Di Masa Pandemi Coronavirus Disease 2019 (Covid-19)," NERSMID J. Keperawatan dan Kebidanan, vol. 4, no. 1, pp. 100-112, 2021.

[10] D. Mayangsari and Y. Fadilah, "Faktor Penyebab Agresivitas Verbal Anak Usia Dini yang Bersekolah di Daerah Pesisir Bangkalan," Pros. Semin. Nas. Call Pap. Psikol. Sos., pp. 37-43, 2019.

[11] Erniwati, "Faktor-Faktor penyebab Orang Tua melakukan Kekerasan Verbal pada Anak Usia Dini," J. Pendidik. Anak usia Dini, vol. 1, no. 1, pp. 1-7, 2020.

[12] D. Erica, Haryanto, M. Rahmawati, and I. A. Vidada, "Peran Orang Tua Terhadap Pendidikan Anak Dalam Perspektif Islam," An-Nidzam J. Manaj. Pendidik. dan Stud. Islam, vol. 3, no. 1, pp. 64-80, 2019.

[13] M. S. S. Hazrina Syahirah Putri, "Pengaruh kekerasan komunikasi verbal orang tua terhadap kepercayaan diri remaja di Provinsi DKI Jakarta," e-Proceeding Manag., vol. 8, no. 1, pp. 666-674, 2021.

[14] N. Indrayati and L. PH, "Gambaran Verbal Abuse Orangtua pada Anak Usia Sekolah," J. Ilmu Keperawatan Anak, vol. 2, no. 1, p. 9, 2019.

[15] DPR \& Presiden Republik Indonesia, "UndangUndang No 35 tahun 2014 Tentang Perlindungan anak," Cell, vol. 3, no. 4, pp. 1-15, 2014.

[16] Y. Fitriana, K. Pratiwi, and A. V. Sutanto, "Faktor-faktor yang berhubungan dengan perilaku orang tua dalam melakukan kekerasan verbal," J. Psikol. Undip, vol. 14, pp. 81-93, 2015.

[17] M. K. B. Iqomh, Y. Susanti, and E. N. Pratiwi, "Status Ekonomi dan Tingkat Pendidikan Orangtua dengan Kejadian Verbal Abuse pada Anak Usia Pra Sekolah,” J. Ilmu Keperawatan Anak, vol. 2, no. 1, p. 34, 2019. 